\title{
Biofilm Formation of Staphylococcus aureus Isolates From Food-Contact Surfaces of Food Processing Environments of Hospitals
}

Jessica Bezerra dos Santos Rodrigues (I), Neyrijane Targino de Souza (I), Vanessa Gonçalves Honório (I), Danilo Elias Xavier (I), Allan de Jesus dos Reis Albuquerque (I), Fábio Correia Sampaio (I), Evandro Leite de Souza (I), Marciane Magnani (I)

(I) UFPB - Universidade Federal da Paraíba (Cidade Universitária - João Pessoa - PB - Brasil CEP: 58051-900)

\section{Resumo}

The surfaces that come into contact with foods are important sources for the transmission of microorganisms in food processing environment. Many pathogenic bacteria are able to form biofilm in food-contact surfaces remaining viable even after cleaning procedures. The capability of S. aureus to form biofilms enhances it survival in food processing environments providing a physiological advantage as etiological agent of foodborne diseases. This study assessed the ability to form biofilm of S. aureus $(n=57)$ isolates from food-contact surfaces of food processing environments of hospitals in the city of João Pessoa, Paraíba, Brazil. The biofilm formation was evaluated in tryptone soy broth after $48 \mathrm{~h}$ of incubation in polystyrene microtiter plates using crystal violet staining and its quantification was based on the difference between the optical density (OD) measurements of the test and negative control samples $\left(\Delta \mathrm{OD}_{492 \mathrm{~nm}}\right)$. The isolates were classified as strong $\left(4 \mathrm{x}_{\mathrm{OD}} \mathrm{D}_{\text {control }}<\mathrm{OD}\right)$, moderate $(2 \mathrm{x}$ OD control $<\mathrm{OD} \leq 4 \mathrm{x}$ OD control), weak $\left(\mathrm{OD}_{\text {control }}<\mathrm{OD} \leq 2 \mathrm{x} \mathrm{OD}_{\text {control }}\right)$ or none (OD $\leq \mathrm{OD}_{\text {control }}$ ) biofilm-producing. The strains S. epidermidis ATTCC 12228 and S. aureus ATTCC 25923 were used as negative and positive (strong producer) control for biofilm formation, respectively. Among the S. aureus biofilm-producers $\Delta \mathrm{OD}_{492 \mathrm{~nm}}$ values ranged from 0.217 to 0.881 . Two

\footnotetext{
Referência:

Jessica Bezerra dos Santos Rodrigues, Neyrijane Targino de Souza, Vanessa Gonçalves Honório, Danilo Elias Xavier, Allan de Jesus dos Reis Albuquerque, Fábio Correia Sampaio, Evandro Leite de Souza, Marciane Magnani. Biofilm Formation of Staphylococcus Aureus Isolates From Food-Contact Surfaces of Food Processing Environments of Hospitals. In: Anais do $12^{\circ}$ Congresso Latinoamericano de Microbiologia e Higiene de Alimentos - MICROAL 2014 [= Blucher Food Science Proceedings, num.1, vol.1]. São Paulo: Editora Blucher, 2014.

DOI $10.5151 /$ foodsci-microal-266
} 
isolates $(3.5 \%)$ was classified as non-biofilm producers $\left(\Delta \mathrm{OD}_{492 \mathrm{~nm}} 0.039\right.$ and 0.041$)$ and two $(3.5 \%)$ were weak biofilm-producers $\left(\Delta \mathrm{OD}_{492 \mathrm{~nm}} 0.08\right.$ and 0.09$)$. However, the most isolates $(n=53 ; 93 \%)$ had ability to form biofilm, classified as moderate $(n=16 ; 28 \%)$ or strong $(n=37 ; 65 \%)$ producers. The high percentage of biofilm-producers among S. aureus isolates studied alert to the risk that this pathogen is as chronic source of contamination, especially in food processing environments to hospitals.

Palavras-Chave: Biofilm, Staphylococcus aureus, Food-contact surfaces Agência de Fomento: 